\title{
PENGARUH KUALITAS PELAYANAN, SANKSI PERPAJAKAN TERHADAP PENGGELAPAN PAJAK DENGAN TEKNOLOGI INFORMASI PERPAJAKAN SEBAGAI VARIABEL MODERASI
}

\author{
Yosi Safri Yetmi \\ ysyetmi@unis.ac.id \\ Program Studi Akuntansi \\ Fakultas Ekonomi dan Bisnis \\ Universitas Islam Syekh Yusuf \\ Tangerang
}

\section{ABSTRAK}

Penelitian ini bertujuan untuk mengetahui kualitas pelayanan, sanksi perpajakan terhadap penggelapan pajak dengan teknologi informasi perpajakan sebagai variable moderasi. Data yang digunakan dalam penelitian ini adalah data primer berupa kuesioner yang disebarkan kepada wajib pajak orang pribadi. Penelitian ini dilakukan melalui metode Convenience Sampling. Sampel dalam penelitian ini dengan cara mendatangi langsung objek penelitian. Jumlah kuesioner yang dibagikan adalah 100, tetapi kuesioner yang dapat diolah 50 lembar. Analisis data dilakukan dengan menggunakan analisis regresi berganda dengan menggunakan SEM PLS.

Hasil penelitian ini membuktikan bahwa kualitas pelayanan berpengaruh signifikan terhadap penggelapan pajak. Sedangkan sanksi perpajakan tidak berpengaruh signifikan terhadap penggelapan pajak. Serta teknologi informasi perpajakan tidak memperkuat pengaruh kualitas pelayanan terhadap penggelapan pajak dan teknologi informasi perpajakan tidak memperkuat pengaruh sanksi perpajakan terhadap penggelapan pajak.

Kata Kunci: Kualitas Pelayanan Pajak, Sanksi Perpajakan, Teknologi Informasi Perpajakan, Penggelapan Pajak.

\section{A. Pendahuluan}

\section{Latar Belakang Penelitian}

Upaya meminimalkan beban pajak dapat dilakukan oleh wajib pajak dengan berbagai cara, mulai dari yang masih berada dalam koridor peraturan perpajakan sampai dengan yang sudah melanggar koridor peraturan perpajakan. Dalam hal ini ada banyak modus yang dilakukan untuk menghindar dari pembayaran wajib pajak. Secara umum modus tindak kejahatan pajak dibagi dalam dua cara yaitu dalam bentuk legal dan illegal. Cara legal dilakukan dengan menghindari pembayaran pajak 
melalui pembukuan penjualan yang dibuat tidak sebagaimana mestinya. Hal ini umumnya dilakukan perusahaan-perusahaan besar yang memiliki sumber daya yang capable dalam hal mensiasati kelemahan peraturan perpajakan. Sementara untuk modus illegal, dilakukan dengan cara penyelundupan atau tidak melaporkan penjualannya. Hal itu bisa dilakukan dengan cara membuat invoice palsu.

Tujuan Negara Indonesia yang tercantum dalam UUD 1945 adalah melindungi segenap bangsa Indonesia dan seluruh tumpah darah Indonesia dan untuk memajukan kesejahteraan umum, mencerdaskan kehidupan bangsa dan ikut melaksanakan ketertiban dunia yang berdasarkan kemerdekaan, perdamian abadi dan keadilan sosial. Dalam mencapai tujuan tersebut tentu saja membutuhkan dana pembangunan yang tidak sedikit. Salah satu wujud dari kemandirian bangsa dalam pembiayaan pembangunan adalah dengan menggali sumber dana yang bersumber dari dalam negeri, salah satunya adalah pajak. ( Supramomo \& Damayanti , 2015)

Penggelapan pajak terjadi sebelum SKP (Surat Ketetapan Pajak) dikeluarkan, hal ini merupakan pelanggaran terhadap undang-undang dengan maksud melepaskan diri dari pajak/mengurangi dasar penetapan pajak dengan cara menyembunyikan sebagian dari penghasilannya. Ini dapat terlihat dengan munculnya kasus Gayus Tambunan 9 tahun lalu yakni pada tahun 2010. Gayus boleh dibilang menjadi ikon kasus pajak di Indonesia. Ingatan kita selalu terlintas nama Gayus, Mantan pegawai pajak golongan IIIA ini diduga menerima gratifikasai dan suap, lalu disimpan di safe deposit box miliknya, sebesar Rp 74 miliar kemudian muncul nama-nama baru seperti Dhana Widyatmika pegawai Direktorat Jendral Pajak golongan IIIC yang menjadi pegawai Dinas Pajak DKI itu, menjadi tersangka kasus dugaan korupsi penggelapan pajak dan kasus Bahasyim yang ditetapkan sebagai tersangka atas kasus pencucian uang dan korupsi sejak 9 april 2010 (www.anneahira.com). 
Beberapa faktor seperti kualitas pelayanan pajak, sanksi perpajakan dan teknologi informasi perpajakan mempunyai pengaruh terhadap penggelapan pajak. Pada penelitian terdahulu terdapat persamaan dan perbedaan hasil penelitian. Beberapa Penelitian yang dilakukan oleh Murni et al (2013), Ayu dan Hastuti (2009) menyatakan kualitas pelayanan pajak berpengaruh signifikan negatif terhadap persepsi wajib pajak mengenai penggelapan pajak. Sanksi perpajakan yang diteliti oleh Latuperrisa (2009) menunjukkan hasil yang berpengaruh positif terhadap penggelapan pajak.

\section{B. Metodologi}

\section{Sumber Data,Populasi dan Sampel}

Populasi dalam penelitian ini adalah seluruh pegawai yang terdaftar dalam KPP Tangerang. Sampel dalam penelitian ini adalah wajib pajak orang pribadi atau responden yang bersedia untuk menjadi objek penelitian. Sampel penelitian diambil dengan menggunakan teknik convenience sampling, dimana pengambilan sampel berdasarkan kesesuaian dengan ketentuan atau persyaratan sampel dari populasi tertentu yang paling mudah untuk dijangkau atau didapatkan, misalnya yang terdekat dengan tempat peneliti berdomisili (Sekaran, 2009).

\section{Teknik Analisis Data}

\section{Model Pengukuran (Outer Model)}

Suatu konsep dan model penelitian tidak dapat diuji dalam suatu model prediksi hubungan relasional dan kausal jika belum melewati tahap verifikasi dalam model pengukuran. Analisa outer model ini menspesifikasi hubungan antar variabel laten dengan indikator-indikatornya. atau dapat dikatakan bahwa outer model mendefinisikan bagaimana setiap indikator berhubungan dengan variabel latennya.Dibawah ini uji pada outer model untuk indikator reflektif. 


\section{a. Uji Validitas Konstruk}

Validitas konstruk menunjukan seberapa baik hasil yang diperoleh dari penggunaan suatu pengukuran sesuai teori teori yang digunakan untuk mendefenisikan suatu konstuk. Uji validitas konstruk secara umum dapat diukur dengan parameter skor loading di model penelitian (Rule of Thumb $>0,5$ ) dengan menggunakan parameter AVE, Communality, $\mathrm{R}^{2}$ dan Redudancy. Skor AVE harus > 0,5, Communality $>$ 0,5, dan Redudancy mendekati 1. Jika scor loading $<0,5$, indikator ini dapat dihapus dari konstruknya karena indikator ini tidak termuad (load) ke konstruk yang mewakilinya (Abdillah dan Jogiyanto, 2015).

a. Uji validitas Konvergen

Parameter uji validitas konvergen dilihat dari skor AVE dan communality, masing-masing harus bernilai diatas 0,5. Artinya probabilitas indikator disuatu konstruk masuk kevariabel lain lebih rendah (kurang 0,5) sehingga probabilitas indikator tersebut konvergen dan masuk dikonstruk yang dimaksud lebih besar yaitu diatas 50 persen.

Ave dapat dihitung dengan rumus:

$$
\mathrm{AVE}=\sum_{k=1}^{n} \vartheta \mathrm{i}^{2}
$$

Communality dapat dihitung dengan rumus:

Communality $=\frac{1}{P j} \sum_{h=1}^{P j} \operatorname{korelasi}^{2}\left(\mathrm{Xjh}, \mathrm{Yj}_{\mathrm{j}}\right)$

\section{b. Uji Validitas Diskriminan}

Untuk uji validitas diskriminan, parameter yang diukur adalah dengan membandingkan akar dari AVE suatu konstruk harus lebih tinggi dibandingkan dengan korelasi antar variabel, atau melihat skor cross loading.

Berikut tabulasi parameter uji validitas dalam PLS 
Tabel 1

Parameter uji validitas dalam model pengukuran PLS

\begin{tabular}{|c|c|c|}
\hline Uji Validitas & Parameter & Rule of Thums \\
\hline \multirow{3}{*}{ Konvergen } & Faktor loading & Lebih dari 0,5 \\
\hline & 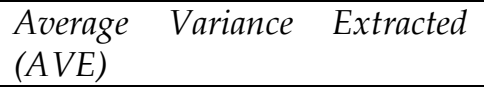 & Lebih dari 0,5 \\
\hline & Communality & Lebih dari 0,5 \\
\hline \multirow[t]{2}{*}{ Diskriminan } & $\begin{array}{l}\text { Akar AVE dan korelasi } \\
\text { variabel laten }\end{array}$ & $\begin{array}{l}\text { Akar AVE > korelasi variabel } \\
\text { laten }\end{array}$ \\
\hline & Cross Loading & $\begin{array}{l}\text { Lebih dari } 0,5 \text { dalam satu } \\
\text { variabel }\end{array}$ \\
\hline
\end{tabular}

Sumber: Abdillah dan Jogiyanto (2015)

\section{Hasil Penelitian}

\section{Evaluasi Model Pengukuran (Outer/Measurement Model)}

\section{a.Validitas Konstruk (Construk Validity)}

Uji validitas konstruk secara umum dapat diukur dengan parameter skor loading dan menggunakan parameter Average Variance Extracted (AVE) dan Communality. Suatu konstruk dinyatakan valid jika skor loading $>0,5$, AVE $>0,5$, dan Communality $>0,5$. Hasil output korelasi antar indikator dengan konstruknya dapat dilihat pada tabel dibawah ini:

Tabel 2

Loading Factor dan AVE

\begin{tabular}{lccc}
\hline & Construct & Loading Factor & AVE \\
\hline KPP & KPP 1 & 0.804 & \\
& KPP 2 & 0.811 & 0.693 \\
& KPP 3 & 0.797 & \\
& KPP 4 & 0.896 & \\
& KPP 5 & 0.849 & 0.532 \\
\hline SP & SP 1 & 0.661 & \\
& SP 3 & 0.672 & \\
& SP 4 & 0.832 & \\
& TIP 1 & 0.844 & \\
TIP & TIP 2 & 0.820 & \\
& TIP 3 & 0.796 & \\
& TIP 4 & 0.846 & \\
\hline PP & TIP 5 & 0.895 & \\
& PP 1 & 0.708 & \\
& PP 2 & 0.787 & \\
& PP 3 & 0.790 & \\
& PP 4 & 0.644 & \\
\hline
\end{tabular}

Sumber: Olahan PLS 2019 
Hasil tabel diatas menyatakan bahwa nilai Loading Factor dan AVE sudah diatas > 0,5.Hasil Tampilan PLS Algorithm:

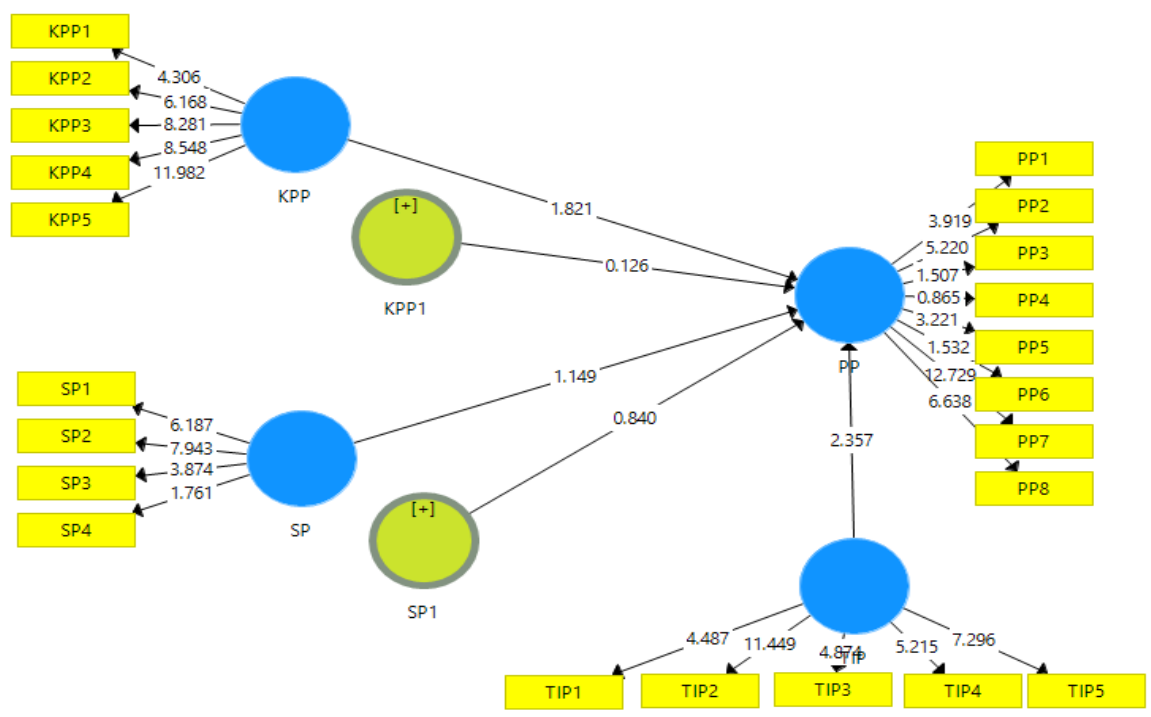

Gambar 1

Tampilan Hasil PLS Algorthm

\section{b. Convergent Validity}

Untuk menilai convergent validity suatu konstruk dapat dilakukan dengan melihat skor average varian extracted (AVE) dan communality, masing-masing harus di atas 0.5.

\section{c. Discriminant Validity}

Discriminant validity dari model pengukuran (outer model) dengan indikator refleksif dinilai berdasarkan cross loading pengukuran dengan konstruk. Jika korelasi konstruk dengan item pengukuran lebih besar daripada ukuran kontruk lainnya, maka hal itu menunjukkan bahwa konstruk laten memprediksi ukuran pada blok mereka lebih baik dari pada ukuran pada blok lainnya. Cross loading untuk seluruh konstruk disajikan padatabel dibawah ini: 
Tabel 3

Cross Loadings

\begin{tabular}{|c|c|c|c|c|}
\hline \multirow[b]{2}{*}{ Item } & \multicolumn{4}{|c|}{ Kontruk } \\
\hline & $\begin{array}{c}\text { Kualitas } \\
\text { Pelayanan } \\
\text { pajak } \\
\text { (KPP) }\end{array}$ & $\begin{array}{c}\text { Sanksi } \\
\text { Perpajakan } \\
(\mathrm{SP})\end{array}$ & $\begin{array}{l}\text { Teknologi } \\
\text { Informasi } \\
\text { Perpajakan } \\
\text { (TIP) }\end{array}$ & $\begin{array}{c}\text { Penggelapan Pajak } \\
\text { (PP) }\end{array}$ \\
\hline KPP 1 & 0.804 & 0.531 & 0.449 & 0.623 \\
\hline KPP 2 & 0.811 & 0.369 & 0.489 & 0.579 \\
\hline KPP 3 & 0.797 & 0.390 & 0.547 & 0.579 \\
\hline KPP 4 & 0.896 & 0.560 & 0.548 & 0.678 \\
\hline KPP 5 & 0.849 & 0.504 & 0.553 & 0.708 \\
\hline SP 1 & 0.151 & 0.661 & 0.216 & 0.270 \\
\hline SP 2 & 0.424 & 0.672 & 0.327 & 0.355 \\
\hline SP 3 & 0.562 & 0.832 & 0.593 & 0.603 \\
\hline TIP 1 & 0.46 & 0.573 & 0.844 & 0.667 \\
\hline TIP 2 & 0.452 & 0.456 & 0.820 & 0.551 \\
\hline TIP 3 & 0.497 & 0.411 & 0.796 & 0.556 \\
\hline TIP 4 & 0.596 & 0.492 & 0.846 & 0.703 \\
\hline TIP 5 & 0.508 & 0.462 & 0.895 & 0.645 \\
\hline PP 1 & 0.419 & 0.417 & 0.443 & 0.708 \\
\hline PP 2 & 0.666 & 0.506 & 0.608 & 0.787 \\
\hline PP 3 & 0.621 & 0.485 & 0.714 & 0.790 \\
\hline PP 4 & 0.499 & 0.351 & 0.356 & 0.644 \\
\hline
\end{tabular}

\section{Sumber: Olahan PLS 2019}

Hasil tabel diatas menyatakan bahwa nilai dari Cross Loading sudah memenuhi diatas 0,5 .

\section{d.Reliability Konstruk (Reliability Construct)}

Reliability konstruk dari measurement model dengn indikator reflektif dapat diukur dengan melihat nilai composite reability dari blok indikator yang mengukur konstruk. Suatu konstruk dikatakan reliabel jika nilai composite reliability di atas 0,7 . Berikut adalah nilai composite reliability yang di sajikan pada tabel di bawah ini: 
Tabel 4

Composite Reliability

\begin{tabular}{lc}
\hline \multicolumn{1}{c}{ Konstruk } & Composite Reliability \\
\hline Kualitas Pelayanan Pajak & 0.840 \\
\hline Sanksi Perpajakan & 0.939 \\
\hline Teknologi Informasi Perpajakan & 0.862 \\
\hline Penggelapan Pajak & 0.850 \\
\hline Sumber: Olahan PLS 2019
\end{tabular}

Sumber: Olahan PLS 2019

Uji reliabilitas juga bisa diperkuat dengan cronbach's alpha dengan nilai konstruknya di atas 0,7 . Berikut adalah nilai cronbach's alpha yang di sajikan pada tabel di bawah ini:

Tabel 5

Cronbach's Alpha

Konstruk Cronbach's Alpha

Kualitas Pelayanan Pajak 0.918

Sanksi Perpajakan 1.000

Teknologi Informasi Perpajakan 0.923

Penggelapan Pajak 0.823

\section{Sumber: Olahan PLS 2019}

\section{Evaluasi Model Struktural (Inner Model)}

\section{a. R-Square}

Pengujian inner model atau model struktural dilakukan untuk melihat hubungan antara konstruk, nilai signifikan dan $R$-square dari model penelitian. Model struktural dievaluasi dengan menggunakan $R$-square untuk konstruk dependen uji t serta signifikan dari koefesien parameter jalur struktural. Dalam menilai model struktural dengan PLS dimulai dengan melihat $R$-square untuk setiap variabel laten dependen. Tabel dibawah ini merupakan hasil estimasi $R$-square dengan menggunakan PLS. 
Tabel 6

R-square dan R-Square Adjusted

\begin{tabular}{lcc}
\hline Variabel Dependen & R-Square & R-Square Adjusted \\
\hline Penggelapan Pajak & 0.751 & 0.738
\end{tabular}

\section{Sumber: Olahan PLS 2019}

\section{b. Pengujian Hipotesa}

Dasar yang digunakan dalam menguji hipotesis adalah nilai yang terdapat pada output path coeficients dimana jika t-statistic bernilai di atas atau sama dengan 1.96 (t-statistic lebih besar dari 1.96), maka pengaruh yang diberikan oleh variabel independen terhadap variabel dependen adalah signifikan secara statistik. Jika t-statistic bernilai di bawah 1,96 (t-statistic lebih kecil dari 1,96), maka pengaruh yang diberikan tidak signifikan secara statistik ((Abdillah dan Jogiyanto, 2015). sebagai berikut:

Tabel 7

Path Coefficients

\begin{tabular}{|c|l|c|c|c|c|}
\hline Hipotesa & Construct & $\begin{array}{c}\text { Origina } \\
\mathbf{1} \\
\text { Sample } \\
\mathbf{( O )}\end{array}$ & $\begin{array}{c}\text { T- } \\
\text { Statistik }\end{array}$ & $\begin{array}{c}\text { P- } \\
\text { Value }\end{array}$ & Kesimpulan \\
\hline 1 & $\mathrm{KPP} \rightarrow \mathrm{PP}$ & 0.460 & $\mathbf{5 . 0 5 0}$ & 0.000 & H1 Diterima \\
\hline 2 & $\mathrm{SP} \longrightarrow \mathrm{PP}$ & 0.080 & $\mathbf{1 . 7 4 1}$ & 1.162 & H2 Ditolak \\
\hline 3 & $\mathrm{TIP} \rightarrow \mathrm{KPP}$ * PP & -0.125 & $\mathbf{1 . 7 1 7}$ & 1.473 & H3 Ditolak \\
\hline 4 & $\mathrm{TIP} \rightarrow \mathrm{SP} * \mathrm{PP}$ & 0.065 & $\mathbf{0 . 7 4 1}$ & 0.459 & H4 Ditolak \\
\hline
\end{tabular}

\section{Sumber: Olahan PLS 2019}

\section{Diskusi}

\section{Pengaruh Kualitas Pelayanan Pajak Terhadap Penggelapan Pajak}

Berdasarkan tabel hipotesis diatas kualitas pelayanan pajak (X1) berpengaruh signifikan terhadap persepsi wajib pajak mengenai penggelapan pajak dengan tingkat signifikan 5,050, sedangkan tingkat alpha $5 \%(0,05)$, dengan demikian hipotesis pertama (H1) diterima yaitu 5,050 > 1,96 yang artinya kualitas pelayanan pajak berpengaruh signifikan terhadap persepsi wajib pajak mengenai penggelapan pajak.

Kualitas pelayanan merupakan kunci utama dari pelayanan publik yang diberikan kepada masyarakat. Kualitas pelayanan merupakan tingkat 
keunggulan yang diharapkan untuk memenuhi keinginan dari wajib pajak. Dengan adanya kualitas pelayanan yang baik dan prima, maka akan tercipta suatu persepsi yang baik dari wajib pajak terhadap pelayanan yang diberikan.

\section{Pengaruh Sanksi Perpajakan Terhadap Penggelapan Pajak}

Berdasarkan Tabel hipotesis kedua yaitu sanksi perpajakan (X2) terhadap persepsi wajib pajak mengenai penggelapan pajak dengan melihat tingkat signifikan 1,741 dan tingkat Alpha $5 \%(0,05)$ dengan demikian hipotesis kedua $(\mathrm{H} 2)$ ditolak yaitu 1,741 < 1,96 artinya sanksi perpajakan tidak berpengaruh signifikan terhadap persepsi wajib pajak mengenai penggelapan pajak.

Dalam UU KUP perpajakan, sanksi dikenakan apabila wajib pajak tidak menyampaikan surat pemberitahuan tepat waktu sesuai dengan jangka waktu yang ditetapkan (Rahayu, 2010). Apabila pihak perpajakan mampu memberikan hukuman yang sesuai dan memberikan efek jera kepada wajib pajak, maka kecurangan terhadap perpajakan tidak akan dilakukan oleh wajib pajak. Namun yang terjadi dilapangan, masyarakat menganggap bahwa pemerintah belum mampu mengatasi tindakkan kecurangan. Teknologi Informasi Perpajakan memoderisasi pengaruh kualitas pelayanan terhadap penggelapan pajak

Berdasarkan hasil tabel diatas menguji tentang teknologi informasi perpajakan memperkuat pengaruh kualitas pelayanan terhadap penggelapan pajak. Di dalam tahapan pengolahan data digunakan sigifikan dengan T-statistik berada di atas 1.96, hasil yang diperoleh 1,717 $<$ 1.96. Dengan demikian dapat disimpulkan bahwa hipotesis ketiga (H3) ditolak, artinya teknologi informasi perpajakan tidak memperkuat pengaruh kualitas pelayanan terhadap penggelapan pajak sebesar 1,717.

3. Teknologi Informasi Perpajakan memoderisasi pengaruh sanksi perpajakan terhadap penggelapan pajak

Berdasarkan hasil tabel diatas menguji tentang teknologi informasi perpajakan memperkuat pengaruh sanksi perpajakan terhadap 
penggelapan pajak. Di dalam tahapan pengolahan data digunakan sigifikan dengan T-statistik berada di atas 1.96, hasil yang diperoleh 0.741 $<$ 1.96. Dengan demikian dapat disimpulkan bahwa hipotesis keempat (H4) ditolak, artinya teknologi informasi perpajakan tidak memperkuat pengaruh sanksi perpajakan terhadap penggelapan pajak.

\section{E. KESIMPULAN}

Penelitian ini bertujuan untuk menguji secara empiris pengaruh variabel independen terhadap variabel dependen Dengan menggunakan alat uji SEM PLS hipotesis yang didapat sebagai berikut:

1. Pengujian hipotesis pertama ditemukan bahwa kualitas pelayanan pajak (X1) berpengaruh signifikan terhadap persepsi wajib pajak mengenai penggelapan pajak dengan tingkat signifikan 5,050, sedangkan tingkat alpha $5 \%(0,05)$, dengan demikian hipotesis pertama (H1) diterima yaitu 5,050 > 1,96 yang artinya kualitas pelayanan pajak berpengaruh signifikan terhadap persepsi wajib pajak mengenai penggelapan pajak.

2. Pengujian hipotesis kedua ditemukan bahwa sanksi perpajakan (X2) terhadap persepsi wajib pajak mengenai penggelapan pajak dengan melihat tingkat signifikan 1,741 dan tingkat Alpha 5 \% $(0,05)$ dengan demikian hipotesis kedua (H2) ditolak yaitu 1,741 < 1,96 artinya sanksi perpajakan tidak berpengaruh signifikan terhadap persepsi wajib pajak mengenai penggelapan pajak.

3. Pengujian hipotesis ketiga ditemukan bahwa teknologi informasi perpajakan memperkuat pengaruh kualitas pelayanan terhadap penggelapan pajak dengan melihat tingkat signifikan 1,717 < 1.96 dengan demikian hipotesis ketiga (H3) ditolak artinya teknologi informasi perpajakan tidak memperkuat pengaruh kualitas pelayanan terhadap penggelapan pajak.

4. Pengujian hipotesis keempat ditemukan bahwa teknologi informasi perpajakan memperkuat pengaruh sanksi perpajakan terhadap penggelapan pajak dengan melihat tingkat signifikan $0.741<1.96$ dengan demikian hipotesis keempat (H4) Ditolak artinya teknologi informasi perpajakan tidak memperkuat pengaruh sanksi perpajakan terhadap penggelapan pajak 


\section{Referensi}

Abdillah., W dan Jogiyanto. 2009. Partial Least Square (PLS) Alternatif SEM Dalam Penelitian Bisnis . Penerbit Andi: Yogyakarta.

Ayu, Dyah dan Rini Hastuti. 2009. Persepsi WP: Dampak Pertentangan

Diametral Pada Tax Evasion WP Dalam Aspek Kemungkinan

Terdeteksinya Kecurangan, Keadilan, Ketepatan Pengalokasian,

Teknologi Sistem Perpajakan, dan Kecenderungan Personal (Studi

WP Orang Pribadi). Kajian akuntansi Vol 1 No 1. gar

Fermatasari, Dewi. 2013. Pen uh Pengetahuan Pajak dan Sanksi Pajak Terhadap Kepatuhan Wajib Pajak . jurnal Akuntansi Universitas Komputer Indonesia.

Fitria, Verisca Dena. 2010. Pengaruh Pengetahuan Perpajakan, Kualitas Pelayanan, Pemeriksaan dan Kesadaran Terhadap Kepatuhan Wajib Pajak Dalam Meyampaikan Surat Pemberitahuan (SPT). Skripsi Universitas Islam Negeri Syarif Hidayatullah.

Jatmiko, Agus Nugroho.2006. Pengaruh Sikap Wajib Pajak Pada Pelaksanaan Sanksi Denda,Pelayanan Fiskus Dan Kesadaran Terhadap Kepatuhan Wajib Pajak. Tesis Universitas diponegoro.

Jufri, Riri Herlina. 2011. Analisis Perbedaan Tingkat Pemahaman Wajib Pajak dan Fiskus Terhadap Perencanaan pajak Dan Penggelapan pajak. Skripsi Universitas Bung Hatta.

Latuperrisa, Wanda. 2009. Pengaruh Persepsi Wajib pajak Orang Pribadi Atas Pengenaan Sanksi Perpajakan Terhadap Meminimalisasikan Tindakan TaxEvasion. Skrispi Universitas Komputer Indonesia.

Mardiasmo. 2011. Perpajakan Edisi Revisi２011. Yogyakarta: Penerbit Andi. 
Masri, Indah dan Dwi Martani. 2012.

Pengaruh Tax Avoidence Terhadap Cost of Debt. PPJK 20, Tesis Fakultas Ekonomi Universitas Indonesia. Jakarta.

Murni, Linda Puspa Sari, Tarjo, dan Erfan Muhammad. 2013. Pengaruh Keadilan, Kualitas Pelayanan Pajak, dan Kemungkinan Terdeteksinya Kecurangan Terhadap Persepsi Wajib Pajak Mengenai Tax evasion. Jurnal Akuntansi Universitas Trunojoyo Madura.

Nickerson, Inge. 2009. Pleshko dan McGee. Presenting the Dimensionality of An Ethics Scale pertaining To Tax Evasion, Journal of Legal, Ethical and Regulatory Issues, Volume 12, Number 1.

Permatasari, Inggrid dan Herry Laksito. 2013. Minimalisasi Tax Evasion Melalui Tarif Pajak, Teknologi dan Informasi Perpajakan, Keadilan, Sistem Perpajakan, dan Ketetapan Pengalokasian Pengeluaran Pemerintah. Di ponegoro Journal OfAccounting Volume 2, Nomor 2,Halaman1- 10. Universitas Diponegoro Semarang.

Rahayu, Siti Kurnia. 2008. Analisis Work Climate, Supportive Management, Terhadap work Effort, dan Taxpayer's Service Quality Yang Mempengaruhi Tax Evasion Di KPP Wilayah Kanwil. Jurnal Ilmiah Vol.7, No.1 Universitas Komputer Indonesia.Majalah Ilmiah Unikom.

Rahayu, Siti Kurnia. 2010. Perpajakan Indonesia. Yogyakarta: Graha Ilmu.

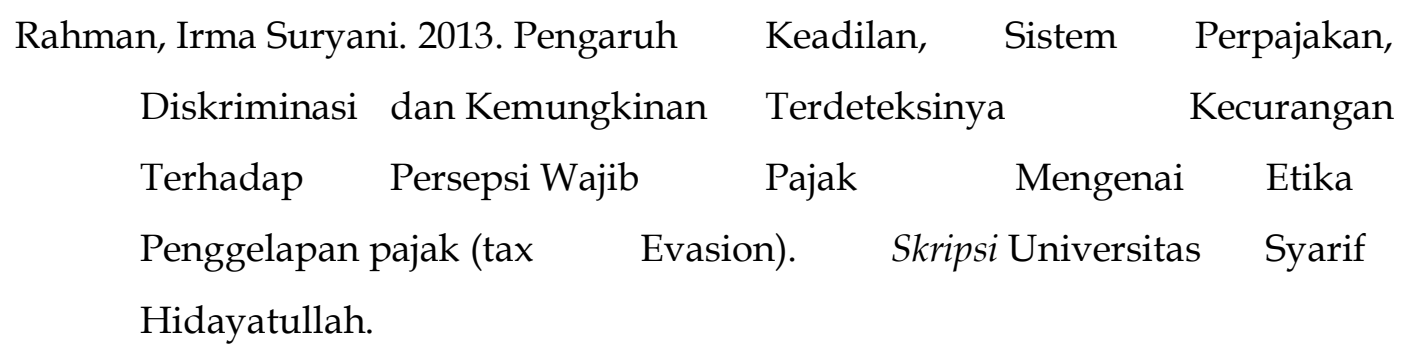


Sekaran, Uma. 2009. Research Method

For Business. Jakarta: salemba Empat.

Suandy, Erly. 2011. Perencanaan Pajak. Jakarta: Salemba empat.

Suminarsasi, Wahyu dan Supriyadi. 2011. Pengaruh Keadilan, Sistem Perpajakan dan Diskriminasi Terhadap Persepsi Wajib Pajak Mengenai Penggelapan Pajak. Tesis Universitas Gajah Mada.

Wahyuningsih, Dian Tri. 2014. Minimalisasi Tax Evasion Melalui Tarif Pajak, Teknologi dan Informasi Perpajakan, Keadilan Sistem Perpajakan, dan Ketepatan Pengalokasian Pengeluaran Pemerintah. Jurnal Ilmiah. Universitas Dian Nusantoro: Semarang.

Waluyo. 2011. Perpajakan Indonesia. Jakarta: Salemba Empat. 